\title{
Population structure of Eupemphix nattereri (Amphibia, Anura, Leiuperidae) from Central Brazil
}

\author{
Daniela de Melo e Silva ${ }^{1,2}$, Aparecido Divino da Cruz ${ }^{1}$, Rogério Pereira Bastos ${ }^{3}$, Raquel Loren Reis ${ }^{1}$ \\ Mariana Pires de Campos Telles ${ }^{4}$ and José Alexandre Felizola Diniz-Filho ${ }^{2,3}$ \\ ${ }^{I}$ Núcleo de Pesquisas Replicon, Departamento de Biologia, Universidade Católica de Goiás, Goiânia, \\ GO, Brazil. \\ ${ }^{2}$ Programa de Pós-Graduação em Biologia Animal, Universidade de Brasília, Brasília, DF, Brazil. \\ ${ }^{3}$ Departamento de Biologia Geral, Instituto de Ciências Biológicas, Universidade Federal de Goiás, \\ Goiânia, GO, Brazil. \\ ${ }^{4}$ Departamento de Zootecnia, Universidade Católica de Goiás, Goiânia, GO, Brazil.
}

\begin{abstract}
This study reports on 156 specimens of the amphibian Eupemphix nattereri, a widely distributed leiuperid, obtained from 11 municipalities of central Brazil. The extent of genetic variation was quantified by determining the mean number of alleles per locus and the proportion of polymorphic loci. An analysis of molecular variance (AMOVA) was performed on the random amplified polymorphic DNA (RAPD) haplotypes. The genetic distances obtained by calculating pairwise $\Phi$ st among local samples were used to determine population relationships using the unweighted pair-group method (UPGMA) and non-metric multidimensional scaling (NMDS). The cophenetic correlation was calculated to confirm agreement between the genetic matrix and the unweighted pair group method with averages (UPGMA) dendrogram. To determine if genetic distances were correlated to geographical distances we constructed pairwise genetic distance and geographical distance matrices and compared them using the Mantel test. The AMOVA results indicated significant genetic differences $(p<0.001)$ between $E$. nattereri populations, representing $69.5 \%$ of the within population genetic diversity. The Mantel test showed no significant correlation $(r=0.03 ; p=0.45)$ between the genetic and geographical distance matrices. Our findings indicate that the genetic variation of $E$. nattereri populations was randomly distributed in geographic space and that gene flow for this species is probably structured at spatial scales smaller than those between our samples
\end{abstract}

Key words: Eupemphix nattereri, gene flow, population structure, RAPD markers.

Received: April 6, 2006; Accepted:March 2, 2007.

\section{Introduction}

Amphibian populations have been the focus of numerous studies that have contributed to the general understanding of ecological and evolutionary phenomena (Newman 1992; Wilbur, 1997; McDiarmid and Altig, 1999; Funk et al., 2005). Amphibians are good models for investigating the genetics of wild animal populations because they are widely distributed in most ecosystems, easy to sample in breeding assemblages and often philopatric to breeding sites. These characteristics can generate high levels of population genetic structure (McDiarmid and Altig, 1999; Beebee, 2005).

Send correspondence to Daniela de Melo e Silva. Universidade Católica de Goiás, Departamento de Biologia, Núcleo de Pesquisas Replicon. Rua 235 n. 40 Cep 74605-010, Goiânia, Goiás, Brazil. E-mail: danielamelo@ucg.br/daniela@ persogo.com.br.
Although a global decline in amphibians has been reported since the 1980 s, relatively little is known about the status of amphibian populations in South American countries due to insufficient data on species distribution and population dynamics, combined with high levels of species diversity (Myers et al., 2000; Young et al., 2001). Information on the population genetic structure of amphibians could help, at least in part, to understand the reason for such declines. Amphibian populations are often thought to have a metapopulation spatial structure (Alford and Richards, 1999), but few studies have actually assessed interpopulation movement, much less the effects of such movement on population dynamics and genetic structure (Newman and Squire, 2001). Amphibians are also thought to have low dispersal rates (Blaustein et al., 1994), although this may not apply to all species (Funk et al., 2005). Low numbers of breeding individuals and limited gene flow between 
populations can reduce genetic diversity in such a way that a species ceases to be viable (Blaustein et al., 1994; Kraaijeveld-Smit et al., 2005; Spear et al., 2005; Telles et. al., 2006).

Neutral genetic markers have been used in studies of amphibian population structures (Rissler et al., 2004; Spear et al., 2005; Telles et. al., 2006). DNA-based markers are capable of disclosing microevolutionary variation and PCR-based genotyping of molecular markers has greatly benefited areas such as population and conservation genetics, allowing the assessment of relatedness and genetic variability between individuals, populations, and species (Avise, 1994; Buso et al., 1998; Zhang and Hewitt, 2003).

Random Amplified Polymorphic DNA (RAPD) is one class of DNA markers used to study the structure of genetic diversity in many species (Wu et al., 2002; Almeida et al., 2003; Telles et al., 2006). This molecular marker can be used for rapid testing, due to its relatively low cost per reaction, the small amounts of DNA needed and the simple method of acquiring data on variation in genomic DNA (Welsh and McClelland, 1990; Hadrys et al., 1992). RAPD markers have been considered suitable for genetic analysis because they allow for examination of accumulated genetic differences that are important at various taxonomic levels (Hardy, 2003). Furthermore, in comparison to codominant markers, dominant markers such as RAPD markers, easily generate a genetic profile even for species to which no prior genetic information is available (Mueller and Wolfenbarger, 1999).

The genus Eupemphix belongs to the anuran family Leiuperidae a widely distributed family which occurs in almost all the Neotropics (Frost, 2007). The genera Eupemphix (Leiuperidae) was described by Steindachner (1863) to include the frog Eupemphix nattereri (Amphibia: Anura: Leptodactylidae), the type locality for which is Cuiabá, in the Brazilian state of Mato Grosso (Nascimento et al., 2005). It is known that E. nattereri is widely distributed in South America, ranging from the east of Paraguay to the mid-east and southeast of Brazil (Frost, 2007) but, however, little is known about the genetic structure of populations of this species or any other frog belonging to this family.

The objective of this study was to investigate the genetic similarity and diversity within and between natural populations of $E$. nattereri from eleven geographical sites in central Brazil using RAPD markers. Genetic and geographic distances were also associated to test whether nearby populations were more genetically similar than distant populations, thus providing the first insight into the microevolutionary processes underlying genetic variation.

\section{Material and Methods}

\section{Sample collection and DNA extraction}

During the rainy seasons (October to March) of 2002-2004 we obtained 156 Eupemphix nattereri specimens from 11 localities in central Brazil, the number of specimens studied in each municipality and the geographic coordinates of the sampling areas are listed in Table 1. Voucher specimens are deposited in Brazil at the Zoological Collection of the Federal University of Goiás (ZUFG). This research was done according to the statutes of COBEA (Brazilian College of Animal Experimentation), once our institution does not have an ethics committee of animal experimentation.

The 156 E. nattereri specimens were humanly sacrificed and liver tissue was removed and stored at $-20^{\circ} \mathrm{C}$ until DNA extraction was performed. Genomic DNA was purified from $20 \mathrm{mg}$ of frozen liver with the Wizard Genomic DNA $^{\circledR}$ purification Kit (Promega Corporation, USA), according to the procedures described by the manufacturer. To estimate the quality and amount of genomic DNA we

Table 1 - The 11 local Eupemphix nattereri populations analyzed, sample sizes, municipalities in the Brazilian state of Goiás and the geographical coordinates.

\begin{tabular}{|c|c|c|c|c|}
\hline Population code & Municipalities & Number of specimens (n) & Latitude (S) & Longitude (W) \\
\hline 1 & Mambaí & 20 & $14^{\circ} 29^{\prime} 16^{\prime \prime}$ & $46^{\circ} 06^{\prime} 47^{\prime \prime}$ \\
\hline 2 & Rio Claro & 11 & $22^{\circ} 24^{\prime} 41^{\prime \prime}$ & $47^{\circ} 33^{\prime} 41^{\prime \prime}$ \\
\hline 3 & Morrinhos & 22 & $17^{\circ} 43^{\prime} 54^{\prime \prime}$ & $49^{\circ} 06^{\prime} 03^{\prime \prime}$ \\
\hline 4 & Aporé & 13 & $18^{\circ} 57^{\prime} 55^{\prime \prime}$ & $51^{\circ} 55^{\prime} 35^{\prime \prime}$ \\
\hline 5 & Chapadão do Sul & 13 & $18^{\circ} 47^{\prime} 39^{\prime \prime}$ & $52^{\circ} 37^{\prime} 22^{\prime \prime}$ \\
\hline 6 & Palmeiras & 10 & $16^{\circ} 48^{\prime} 18^{\prime \prime}$ & $49^{\circ} 55^{\prime} 33^{\prime \prime}$ \\
\hline 7 & Cristianópolis & 13 & $17^{\circ} 11^{\prime} 96^{\prime \prime}$ & $48^{\circ} 42^{\prime} 14^{\prime \prime}$ \\
\hline 8 & Alto Paraíso & 21 & $14^{\circ} 07^{\prime} 57^{\prime \prime}$ & $47^{\circ} 30^{\prime} 36^{\prime \prime}$ \\
\hline 9 & Quirinópolis & 13 & $18^{\circ} 26^{\prime} 54^{\prime \prime}$ & $50^{\circ} 27^{\prime} 06^{\prime \prime}$ \\
\hline 10 & Cocalzinho & 12 & $15^{\circ} 47^{\prime} 40^{\prime \prime}$ & $48^{\circ} 46^{\prime} 33^{\prime \prime}$ \\
\hline 11 & Goiás & 8 & $15^{\circ} 56^{\prime} 04^{\prime \prime}$ & $50^{\circ} 08^{\prime} 25^{\prime \prime}$ \\
\hline Total & 11 & 156 & & \\
\hline
\end{tabular}


subjected $5 \mu \mathrm{L}$ samples of extracted product to electrophoresis on $1 \%(\mathrm{w} / \mathrm{v})$ agarose gel at $5 \mathrm{~V} \mathrm{~cm}^{-1}$ for $30 \mathrm{~min}$. When necessary, the samples were diluted to $2.5 \mathrm{ng} \mu \mathrm{L}^{-1}$.

\section{Random amplified polymorphic DNA (RAPD) analysis}

A total of 40 primers of 10 base pairs were tested to select those with the best amplification pattern. A preliminary screening was performed with DNA from two frogs from the studied populations and allowed the identification of eight RAPD primers (Table 2) that yielded distinct, well-separated and reproducible bands. These bands were subsequently chosen for final analyses. Band repeatability for each primer was confirmed by duplicated PCRs with DNA from at least two frogs from each population sampled. Amplification patterns obtained from two independent sets of PCR reactions using DNA from the Mambai population $(n=20)$ were scored twice by two different technicians to test the technical reproducibility and the reliability of the software Image Master 1D system for interpreting and analyzing RAPD markers. Loci that did not reproduce were excluded from the analyses, as well as unclear and undefined bands. The presence of a determined locus was confirmed by the Total Lab Master 1D software (Amersham Pharmacia Biotech, USA) by verifying the peaks of the bands produced during gel analyses. Loci with peaks smaller than 20 pixels, after two repetitions, were excluded from the analyses (Figure 1). A binary matrix was constructed from the gel readings, where the samples from the individual frogs were genotypically characterized for the presence (1) or absence (0) of bands. The percentage of polymorphism obtained with each primer was calculated from this matrix.

\section{Data analysis}

The extent of genetic variation in each population was quantified by determining the mean number of alleles per locus and the proportion of polymorphic loci, using the TFPGA (Tools for population genetic analyses) v 1.3 soft-

Table 2 - Random amplified polymorphic DNA (RAPD) primers, primer sequences and the number of polymorphic loci used in the population study of Eupemphix nattereri from Central Brazil.

\begin{tabular}{lcc}
\hline Primers & Primer sequences $5 \rightarrow 3$ & Polymorphic loci \\
\hline OPA13 & CAGCACCCCAC & 14 \\
OPB04 & GGACTGGAGT & 7 \\
OPB06 & TGCTCTGCCC & 7 \\
OPB07 & GGTGACGCAG & 13 \\
OPB10 & CTGCTGGGAC & 10 \\
OPB11 & GTAGACCCGT & 12 \\
OPB18 & CCACAGCAGT & 6 \\
OPC20 & ACTTCGCCAC & 12 \\
\hline Total & - & 81 \\
\hline
\end{tabular}

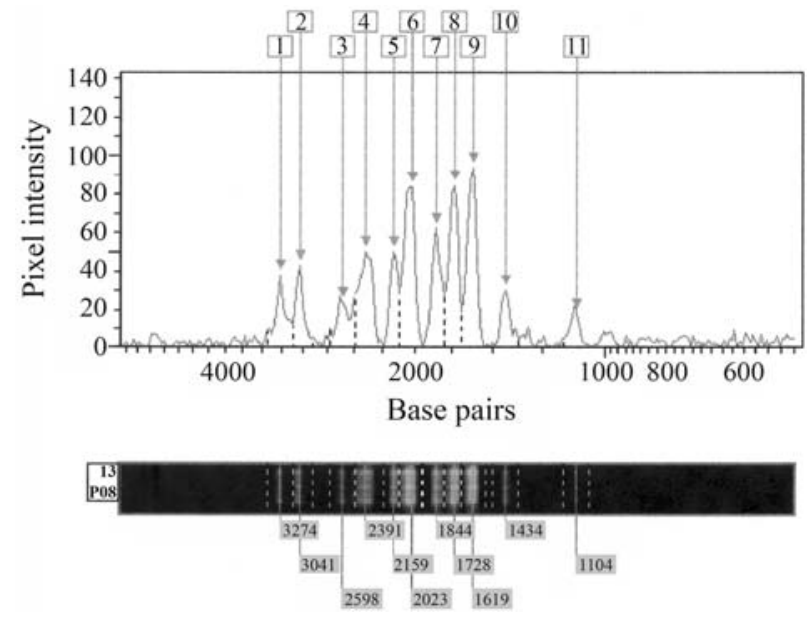

Figure 1 - Random amplified polymorphic DNA marker analysis using the OPA13 primer and one Eupemphix nattereri specimen from Palmeiras municipality. The analysis was made using the Image Master 1D software (Amersham Pharmacia Biotech, USA). The amplicons varied from 1104 to $3274 \mathrm{bp}$ and band intensity ranged from 20 to 90 pixels for eleven amplified loci.

ware (Miller, 1997). Analysis of molecular variance (AMOVA) was performed on the RAPD haplotypes and the Euclidean distances between all pairs of haplotypes were calculated (Excoffier et al., 1992). The AMOVA was used to partition the total genetic variation into that occurring within and among population, expressed by the $\Phi$ st statistic and tested by randomization using 1,000 permutations. These analyses were performed with WINAMOVA software provided by L. Excoffier (University of Geneva).

The $\Phi$ st statistic was also estimated between pairs of local populations, providing an explicit estimate of genetic divergence among local populations to be further used for spatial analyses. Another direct estimate of $\mathrm{F}_{\mathrm{st}}$ from dominant markers was obtained using the Bayesian approach proposed by Holsinger et al. (2002), which does not make explicit assumptions about inbreeding and Hardy-Weinberg equilibrium in local populations. An a posteriori distribution of the $\theta^{\mathrm{B}}$ estimator (an estimate of $\mathrm{F}_{\mathrm{ST}}$ ) was numerically approximated by a Markov Chain Monte Carlo (MCMC) simulation, and tended to converge to a beta distribution. The HICKORY v 1.0 software (Holsinger and Lewis, 2003) allows the estimation of four different models. The first is a full model, in which both $\theta^{\mathrm{B}}$ and $f$ (similar to $F_{\text {IS }}$, the inbreeding coefficient) are estimated. Alternatively, other two models can assume $\theta^{\mathrm{B}}$ or $f$ equal to zero. Finally, because estimates of $f$ based on dominant markers may often be strongly biased, especially for small sample sizes $(\mathrm{n}<10)$, the HICKORY program allows the estimation of a final model in which $f$ is free to vary. The sampler will not attempt to estimate $f$ and instead it will choose values of $f$ at random from its prior distribution while estimating other parameters during the MCMC run. These models were compared using the deviant information criterion 
(DIC), with smaller DIC values indicating the best model. Estimates of $\theta^{\mathrm{B}}$ and other parameters obtained in this way incorporate all of the uncertainty in the prior $f$ value (Holsinger, 1999; Holsinger et al., 2002; Spiegelhalter et al., 2002; Holsinger and Wallace, 2004).

The genetic distances obtained by calculating pairwise $\Phi$ st values between local samples were used to determine population relationships using the unweighted pair group method with averages (UPGMA) (Sneath and Sokal, 1973). Cophenetic correlation using the NTSYS (Numerical Taxonomy and Multivariate Analysis System) software (Rohlf, 1989) was used to verify agreement between the genetic matrix and the UPGMA dendrogram. A high correlation coefficient with a cophenetic correlation $>0.8$ indicates a dendrogram that well reflects the original data but for values lower than 0.8 the clustering result for individual samples should be carefully checked.

Despite the fact that the UPGMA method is one of the methods most frequently used to represent multivariate genetic distances, some authors suggested that hierarchical structures do not always appear in genetic similarity since evolutionary processes tend to generate continuously clinal or reticulate patterns (Lessa 1990; Rodrigues and DinizFilho, 1998). In this case, ordination techniques, such as non-metric multidimensional scaling (NMDS), could also be useful for describing population divergence. Starting from the multidimensional genetic distances, the NMDS program uses iteration to produce the best possible representation of the relationship among populations in a space with a lower number of dimensions (in this paper, a twodimensional (2-D) solution was used), by minimizing the stress $(S)$ value, a measure of "badness-of-fitness".

In order to determine whether genetic distances, based on pairwise $\Phi_{\text {st }}$ values, were correlated with geographical distances Mantel tests were performed using the
NTSYS statistical package program (Manly, 1997; Rohlf, 1989). Matrix correlation was tested using 1,000 random permutations. To refine the Mantel statistics and detect short-distance spatial patterns, analyses were also performed by comparing genetic distances with the binary model matrix $(1 / 0)$ connecting sampling sites situated only at distances of less than $50 \mathrm{~km}$ or $100 \mathrm{~km}$, forming a spatial correlogram at small geographical distances.

\section{Results}

The eight primer sets amplified a total of 82 scorable RAPD fragments in 156 frogs from the 11 populations studied, with 81 (98.8\%) of the 82 loci being polymorphic and only one locus being monomorphic. The variation in band size ranged from approximately 100 to $2000 \mathrm{bp}$ and the number of RAPD fragments per primer varied from 06 to 14 considering all populations (Table 2). Primer set OPA13 produced the highest number of fragments among all the primers used, with an average of 14 loci (Figure 2). On the other hand, primer set OPB18 produced the lowest number of fragments with an average of 6 loci. All primers resulted in polymorphic banding patterns both between and within populations.

The AMOVA results indicated significant genetic differences $(\mathrm{p}<0.001)$ between $E$. nattereri populations (Table 3). The $\Phi_{\mathrm{ST}}$, analogous to $\mathrm{F}_{\mathrm{ST}}$ (Excoffier et al., 1992), was equal to 0.3 , indicating a large amount of interpopulational variation. Of the four models obtained using the Bayesian approach (Table 4), the model with the smaller DIC value (3303.4) was the full model, in which the $\theta^{\mathrm{B}}$ value was equal to 0.36 . However, in this model, the $f$ value was high $(f=0.87)$, probably the result of an artifact due to the small sample sizes and high number of loci (Holsinger and Lewis, 2003). The free $f$-model was the second best one according to the DIC value (3350.1), with

Ld Q09 Q10 Q11 Q12 P01 P02 P03 P04 P05 P06 P07 P08 M01M02 M03 M04 M05M06 M07 M08 M09

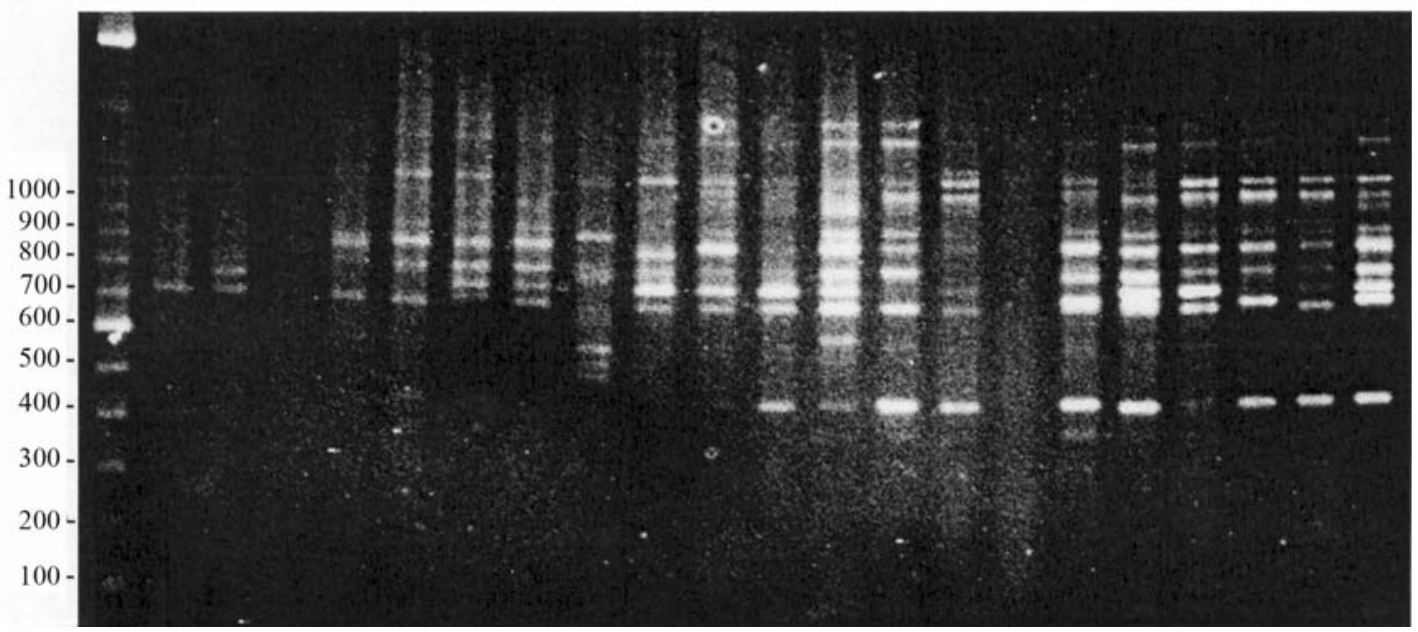

Figure 2 - Random amplified polymorphic DNA PCR patterns for the OPA13 primer in specimens of Eupemphix nattereri from three different municipalities $(\mathrm{Q}=$ Quirinópolis; $\mathrm{p}=$ Palmeiras; and $\mathrm{MO}=$ Morrinhos $) . \mathrm{Ld}=$ molecular weight marker. 
Table 3 - Analysis of Molecular Variance (AMOVA) based on 82 random amplified polymorphic DNA (RAPD) loci for all populations of Eupemphix nattereri from Central Brazil.

\begin{tabular}{|c|c|c|c|c|c|c|c|c|}
\hline $\begin{array}{l}\text { Source of } \\
\text { variation }\end{array}$ & $\begin{array}{l}\text { Degrees of } \\
\text { freedom }\end{array}$ & $\begin{array}{c}\text { Sum } \\
\text { of squares }\end{array}$ & $\begin{array}{l}\text { Mean } \\
\text { square }\end{array}$ & Variance & $\begin{array}{c}\text { Total variance } \\
(\%)\end{array}$ & $\begin{array}{c}\text { Probability } \\
\text { value }\end{array}$ & $\begin{array}{c}\phi_{\text {st }} \\
\text { coefficient }\end{array}$ & $\begin{array}{l}\text { Bartlet's } \\
\text { statistics }\end{array}$ \\
\hline Population & 10 & 956.78 & 95.68 & 5.86 & $30.41 \%$ & $<0.001$ & 0.304 & 0.88 \\
\hline Individual & 145 & 1944.36 & 13.41 & 13.41 & $69.59 \%$ & $<0.001$ & & \\
\hline
\end{tabular}

Table 4 - Bayesian analysis of population divergence for 11 local populations of Eupemphix nattereri using the HICKORY version 1.0 program including the tested models, the estimates of $f$ and $\theta^{\mathrm{B}}$ and the deviant information criterion (DIC).

\begin{tabular}{lccc}
\hline Model & $f$ & $\theta^{\mathrm{B}}$ & DIC \\
\hline full & 0.8689 & 0.3579 & 3303.4324 \\
$f=0$ & - & 0.2886 & 3357.2500 \\
$\theta^{\mathrm{B}}=0$ & 0.8314 & - & 7255.7819 \\
free $f$ & 0.5133 & 0.3411 & 3350.1127 \\
\hline
\end{tabular}

$\theta^{\mathrm{B}}=0.34$ and $f=0.51$, but this free $f$ model was only slightly better than the $f=0$ model, in which $\theta^{\mathrm{B}}$ was equal to $0.29(\mathrm{DIC}=3357.2)$. The worst of all models was the one in which $\theta^{\mathrm{B}}$ was equal to zero (DIC $\left.=7255\right)$. So, the Bayesian approach supports results from AMOVA, suggesting a significant between-population component of genetic variation of about $30 \%$.

Pairwise $\Phi_{\text {st }}$ values ranged from 0.23 to 0.42 (Table 5) and its representation using the two multivariate procedures was not very satisfactory considering the relatively low UPGMA cophenetic correlation coefficient (Figure 3 ) and the high NMDS stress value for a bi-dimensional solution $(S=0.36)$. However, increasing the NMDS stress value to a 3-D solution did not improve the stress, so a 2-D visualization was shown (Figure 4). The 2-D NMDS space did not reveal a clear correspondence with the spatial distri-

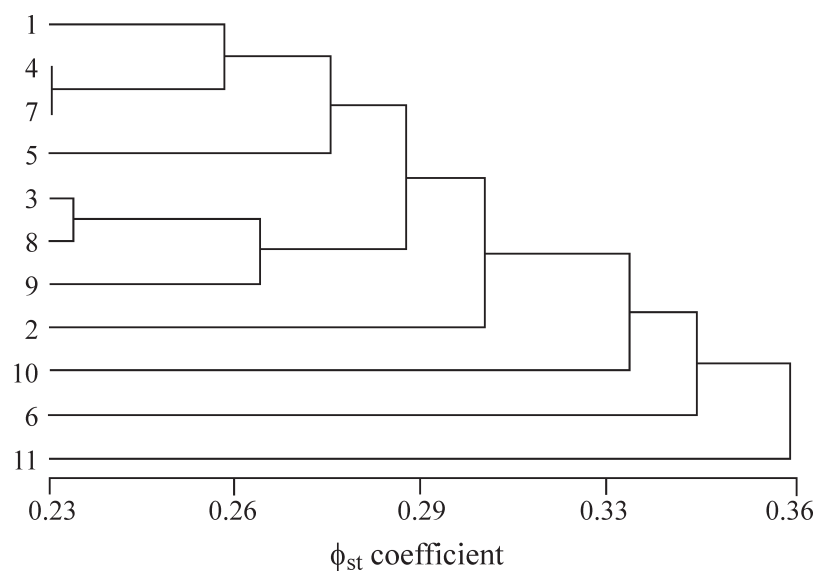

Figure 3 - Unweighted pair group method with averages (UPGMA) dendrogram showing the genetic distance between eleven Eupemphix nattereri populations based on genetic divergence $\left(\Phi_{\mathrm{st}}\right)$.

bution of local populations. Local populations 2 and 11 were in opposed genetic space, these populations being in the extreme positions along the northeast-southwest geographical axis. On the other hand, populations such as 1 and 7 , which were separated by larger distances, were close in genetic space. Some groups of populations close in geographic space (such as 1 and $8 ; 3$ and 7) were also close in genetic space.

Thus, no clear spatial structure was apparent either from the UPGMA or NMDS methods. Indeed, the Mantel

Table 5 - Matrix of $\Phi_{\mathrm{ST}}$ values for each pairwise combination of 11 Eupemphix nattereri populations based on 82 random amplified polymorphic DNA (RAPD) loci.

\begin{tabular}{|c|c|c|c|c|c|c|c|c|c|c|c|}
\hline Population & 1 & 2 & 3 & 4 & 5 & 6 & 7 & 8 & 9 & 10 & 11 \\
\hline 1 & 0 & & & & & & & & & & \\
\hline 2 & 0.309 & 0 & & & & & & & & & \\
\hline 3 & 0.263 & 0.318 & 0 & & & & & & & & \\
\hline 4 & 0.264 & 0.283 & 0.249 & 0 & & & & & & & \\
\hline 5 & 0.287 & 0.329 & 0.311 & 0.241 & 0 & & & & & & \\
\hline 6 & 0.309 & 0.362 & 0.285 & 0.375 & 0.310 & 0 & & & & & \\
\hline 7 & 0.253 & 0.285 & 0.236 & 0.227 & 0.305 & 0.334 & 0 & & & & \\
\hline 8 & 0.289 & 0.282 & 0.232 & 0.318 & 0.289 & 0.316 & 0.278 & 0 & & & \\
\hline 9 & 0.305 & 0.333 & 0.258 & 0.354 & 0.321 & 0.392 & 0.280 & 0.272 & 0 & & \\
\hline 10 & 0.293 & 0.362 & 0.271 & 0.341 & 0.376 & 0.411 & 0.341 & 0.308 & 0.357 & 0 & \\
\hline 11 & 0.362 & 0.401 & 0.253 & 0.334 & 0.394 & 0.409 & 0.302 & 0.386 & 0.417 & 0.347 & 0 \\
\hline
\end{tabular}




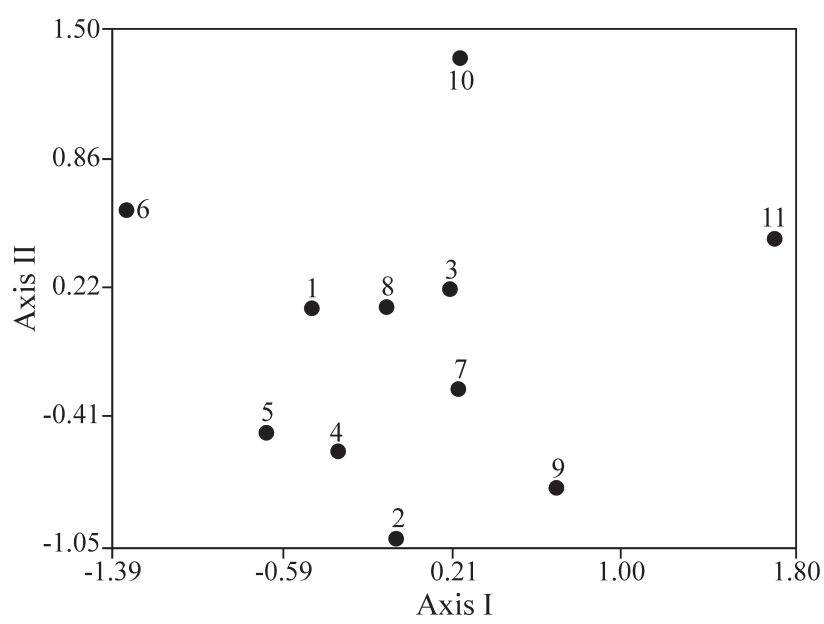

Figure 4 - Two-dimensional plot showing the relative position of the 11 local Eupemphix nattereri populations in pairwise genetic space $\left(\Phi_{\mathrm{ST}}\right)$ reduced by non-metric multidimensional scaling (NMDS).

test showed no globally significant correlation between pairwise $\Phi_{\text {st }}$ values and geographical distances $(r=0.03$; $\mathrm{p}=0.45$ ) (Figure 5). Moreover, no spatial structure appeared when comparing genetic distances with short-distance connectivity matrices, situated at distances of less than $50 \mathrm{~km}$ $(\mathrm{r}=0.05, \mathrm{p}=0.37)$ or $100 \mathrm{~km}(\mathrm{r}=0.02 ; \mathrm{p}=0.45)$.

\section{Discussion}

The RAPD markers indicated that there is a significant population structure of $E$. nattereri in Goiás State, as found for many other species of anurans worldwide (Lampert et al., 2003; Palo et al., 2004; Smith and Green, 2004 Telles et al., 2006). Although both AMOVA and Bayesian analyses showed a significant interpopulational variance component of about $30 \%$, the observed population differentiation was not structured in geographic space, as shown by the Mantel tests and NMDS analyses. According

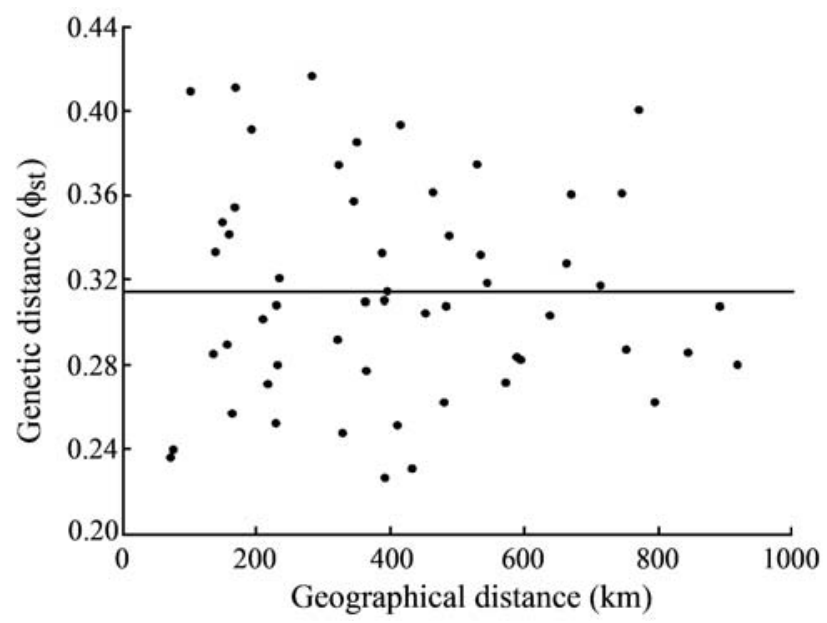

Figure 5 - Graphical representation of the Mantel test results between the geographic and genetic distances for Eupemphix nattereri populations in central Brazil. to these results, for the relationship between genetic and geographic distances, patterns of population differentiation would approximate to Wright's island model. In our case, allele frequencies in each population are allowed to drift independently without relation to the geographic distances separating them. This pattern probably arises because natural populations are of finite size and dispersal is usually constrained to some extent by geographic distance (see Hutchinson and Templeton, 1999). This is indeed to be expected for E. nattereri, for which high levels of population differentiation could arise because this species reproduces only in the beginning of the rainy season, a fact that contributes to the limited dispersion of individual frogs and high site fidelity.

Our data was in partial agreement with a recent RAPD marker study involving 18 populations of the barker frog Physalaemus cuvieri also sampled in Goiás State (Telles et al., 2006). In that study, only short-distances $(>100 \mathrm{~km})$ structure was found, but not an overall significant correlation between genetic and geographical distances. These results confirmed that amphibian populations tend to be relatively isolated from each other, due to reduced gene flow and absence of migration, even at a fine scale, tending to generate and maintain high levels of genetic population structure (Rowe et al., 1998; Lampert et al., 2003; Burns et al., 2004; Palo et al., 2004).

Our E. nattereri results were very similar to those for the British marsh frog Rana ridibunda in the study conducted by Zeisset and Beebee (2003) using RAPD and microsatellite markers. These authors found that $24.7 \%$ of the total variance was between populations and $72.6 \%$ was within populations and the $\Phi_{\mathrm{st}}$ coefficient estimated significant genetic differentiation between most of the $R$. ridibunda populations studied. A microsatellite marker population study was carried out on Bufo calamita, sampled at distances between 0.5 and $9.0 \mathrm{~km}$, by Rowe et al. (2000) who found an average $\Phi_{\mathrm{st}}$ value of 0.11 , lower than the value found by us for our $E$. nattereri study. However, other genetic structure studies have reported even higher $\Phi_{\text {st }}$ values, e.g. the Geocrinia rosea allozymes study by Driscoll (1998), which reported a $\Phi_{\mathrm{st}}$ of 0.6, and the Bufo canorus single-strand conformation polymorphism study by Shaffer et al. (2000), which found a $\Phi_{\text {st }}$ value of 0.2. All the reported studies using amphibians have indicated that ecological and behavioral factors can also create genetic structures at local scales according to the species studied (Palo et al., 2004; Rissler et al., 2004; Rowe and Beebee, 2004). In fact, the $\Phi_{\text {st }}$ value found in our group is higher when compared to other groups, because our geographical range varied from $71 \mathrm{~km}$ to $916 \mathrm{~km}$.

Thus, some amphibian species also presented high genetic structuring, even when populations sampled were less than $5 \mathrm{~km}$ apart (Rowe et al., 2000; Lampert et al., 2003; Burns et al., 2004). Significant $\mathrm{F}_{\mathrm{st}}$ and $\Phi_{\mathrm{st}}$ values 
found in amphibian populations indicate that dispersal is low, even between pools in close proximity (KraaijeveldSmit et al., 2005) and, in our case, the genetic structuring of E. nattereri could be also explained by local extinction and recolonization by a few individual frogs from one or a few source populations. However, we can make no further comments on past fragmentation or other types of range fluctuations since we only sampled a small subset of the species range. Our results presented in this paper provided a preliminary indication of the population structure of $E$. nattereri, and while RAPD markers are insufficient to infer phylogeographic processes mitochondrial DNA analyses could be used to test these predictions.

Our results have revealed that E. nattereri presented high levels of genetic differentiation. However, the genetic variation between $E$. nattereri populations was randomly distributed in geographic space and, probably, gene flow was structured at spatial scales smaller than those between our samples. As mentioned above, in the absence of migration-drift equilibrium mediated by geographic space, populations are weakly connected and a large amount of random differentiation between populations is to be expected. In conclusion, this study has greatly improved our knowledge on the genetic diversity of Eupemphix nattereri. Sampling more sites and the use of different markers would be necessary to test for historical evolutionary forces that shape species population structure.

\section{Acknowledgments}

The authors thank Leôncio Pedrosa Lima, Lorena Dall'ara Guimarães and William Vaz Silva for their help in fieldwork. We also thank Sean Quail for support with the English. This study was undertaken under IBAMA permit 017/05 - RAN. This work was supported by several grants, including Conselho Nacional de Desenvolvimento Científico Tecnológico (CNPq, proc. N. 520804/99-6, 465137/ 00-8, and 474.189/03-1) and by PRONEX program of CNPq/SECTEC-GO (proc. 23234156). RPB and JAFD-F have been supported by CNPq under the researcher productivity fellowships and by Fundação de Amparo à Pesquisa/ Universidade Federal de Goiás (FUNAPE/UFG). DMS, ADC and MPCT have been continuously supported by grants from the Pró-Reitoria de Pós-Graduação e Pesquisa (PROPE)/Universidade Católica de Goiás.

\section{References}

Almeida FS, Sodré LMK and Contel EPB (2003) Population structure analysis of Pimelodus maculatus (Pisces, Siluriformes) from the Tietê and Paranapanema Rivers (Brazil). Genet Mol Biol 26:301-305.

Alford RA and Richards SJ (1999) Global amphibian declines: A problem is applied ecology. Annu Rev Ecol Syst 30:133165 .

Avise JC (1994) Molecular Markers, Natural History and Evolution. Chapman and Hall, New York, 669 pp.
Beebee TJ (2005) Conservation genetics of amphibians. Heredity 95:423-427.

Blaustein AR, Wake DB, and Sousa WP (1994) Amphibian declines: Judging stability, persistence, and susceptibility of populations to local and global extinctions. Conserv Biol 8:60-71.

Burns EL, Eldrigde MDB and Houlden BA (2004) Microsatellite variation and population structure in a declining Australian hylid Litoria aurea. Mol Ecol 13:1745-1757.

Buso GSC, Rangel PH and Ferreira ME (1998) Analysis of genetic variability of South American wild rice populations (Oryza glumaepatula) with isozymes and RAPD markers. Mol Ecol 7:107-117.

Driscoll DA (1998) Genetic structure of the frogs Geocrinia lutea and Geocrinia rosea reflects extreme population divergence and range changes, not dispersal barriers. Evolution 52:1147-1157.

Excoffier L, Smouse PE and Quattro JM (1992) Analysis of molecular variance inferred from metric distances among DNA haplotypes: Application to human mitochondrial DNA restriction data. Genetics 131:479-491.

Hadrys H, Balik M and Schierwater B (1992) Application of random amplified polymorphic DNA (RAPD) in molecular ecology. Mol Ecol 1:55-63.

Hardy OJ (2003) Estimation of pairwise relatedness between individuals and characterization of isolation-by-distance processes using dominant genetic markers. Mol Ecol 12:15771588 .

Holsinger KE (1999) Analysis of genetic diversity in geographically structured populations: A Bayesian perspective. Hereditas 130:245-255.

Holsinger KE, Lewis PO and Dey DK (2002) A Bayesian method for analysis of genetic population structure with dominant marker data. Mol Ecol 11:1157-1164.

Holsinger KE and Lewis PO (2003) HICKORY: v 1.0. A Package for Analysis of Population Genetic Data, 1.0 edn. Storrs. Department of Ecology and Evolutionary Biology, The University of Connecticut. http://www/eeb.uconn.edu/.

Holsinger KE and Wallace LE (2004) Bayesian approaches for the analysis of population genetic structure: An example from Platanthera leucophae (Orchidaceae). Mol Ecol 13:887-894.

Hutchison DW and Templeton AR (1999) Correlation of pairwise genetic and geographic distance measures: Inferring the relative influences of gene flow and drift on the distribution of genetic variability. Evolution 53:1898-1914.

Kraaijeveld-Smit FJL, Beebee TJC, Griffiths RA, Moore RD and Schley L (2005) Low gene flow but high genetic diversity in the threatened Mallorcan midwife toad Alytes muletensis. Mol Ecol 14:3307-3315.

Lampert KP, Rand AS, Mueller UG and Ryan MJ (2003) Finescale genetic pattern and evidence for sex-biased dispersal in the tungara-frog, Physalaemus pustulosus. Mol Ecol 12:3325-3334.

Lessa E (1990) Multidimensional analysis of geographic genetic structure. Syst Zool 39:242-252.

Manly BFJ (1997) Randomization, Bootstrap and Monte Carlo Methods in Biology. Chapman and Hall, London, 399 pp.

McDiarmid RW and Altig R (1999) Tadpoles: The Biology of Anuran Larvae. University of Chicago Press, Chicago, $458 \mathrm{pp}$. 
Miller MP (1997) Tools for Population Genetic Analyses (TFPGA), version 1.3: A Windows Program for the Analysis of Allozyme and Molecular Population Genetic Data. Flagstaff, University of Northern Arizona. http://herb.bio. nau.edu/ miller/tfpga.htm.

Mueller UG and LL Wolfenbarger (1999) AFLP genotyping and fingerprinting. Trends Ecol Evol 14:389-394.

Myers N, Mittermeier RA, Mittermeier CG, Fonseca GAB and Kent J (2000) Biodiversity hotspots for conservation priorities. Nature 403:853-858.

Nascimento LB, Caramaschi U and Cruz CAG (2005) Taxonomic review of the species groups of the genus Physalaemus Fitzinger, 1826. Arq Mus Nac 63:297-320.

Newmann RA (1992) Adaptative plasticity in amphibian metamorphosis. Bioscience 42:671-678.

Newman RA and Squire T (2001) Microsatellite variation and fine-scale population structure in the wood frog (Rana sylvatica). Mol Ecol 10:1087-1100.

Palo JU, Schmeller DS, Laurila A, Primmer CR, Kuzmin SL and Merila J (2004) High degree of population subdivision in a widespread amphibian. Mol Ecol 13:2631-2644.

Rissler LJ, Wilbur HM and Taylor DR (2004) The influence of ecology and genetics on behavioral variation in salamander populations across the Eastern Continental Divide. Am Nat 164:201-213.

Rodrigues FM and Diniz-Filho JAF (1998) Hierarchical structure of genetic distances: Effects of matrix size, spatial distribution and correlation structure among gene frequencies. Genet Mol Biol 21:233-240.

Rohlf FJ (1989) NTSYS-pc: Numerical Taxonomy and Multivariate Analysis System (Manual). Exeter Publishers, New York.

Rowe G and Beebee TJC (2004) Reconciling genetic and demographic estimators of effective population size in the anuran amphibian Bufo calamita. Conserv Genetics 5:287-298.

Rowe G, Beebee TJC and Burke T (1998) Phylogeography of the natterjack toad Bufo calamita in Britain: Genetic differentiation of native and translocated populations. Mol Ecol 7:751-760.

Rowe G, Beebee TJC and Burke T (2000) A microsatellite analysis of natterjack toad, Bufo calamita, metapopulations. Oikos 88:641-651.

Shaffer HB, Fellers GM, Magee A and Voss SR (2000) The genetics of amphibian declines: Population substructure and molecular differentiation in the Yosemite toad, Bufo canourus (Anura, Bufonidae) based on single strand conformation polymorphism analysis (SSCP) and mitochondrial DNA sequence data. Mol Ecol 9:245-257.
Smith MA and Green DM (2004) Phylogeography of Bufo fowleri at its northern range limit. Mol Ecol 13:3723-3733.

Sneath PHA and Sokal RP (1973) Numerical Taxonomy. WH Freeman and Company, San Francisco, 573 pp.

Spear SF, Peterson CR, Matocq MD and Storfer A (2005) Landscape genetics of the blotched tiger salamander (Ambystoma tigrinum melanostictum). Mol Ecol 14:2553-2564.

Spiegelhalter DJ, Best NG, Carlin BP and Linde VD (2002) Bayesian measures of model complexity. J R Stat Soc [Series B] 64:483-689.

Telles MPC, Bastos RP, Soares TN, Resende LV and Diniz-Filho JAF (2006) RAPD variation and population genetic structure of Barker frog Physalaemus cuvieri (Anura, Leptodactylidae) in Central Brazil. Genetica 128:323-332.

Welsh J and McClelland M (1990) Fingerprinting genomes using PCR with arbitrary primers. Nucleic Acid Res 18:72137218.

Wilbur HM (1997) Experimental ecology of food webs: Complex systems in temporary ponds. Ecology 78:2279-2302.

Wilson AJ, Hutchings JA and Ferguson MM (2004) Dispersal in a stream dwelling salmonid: Inferences from tagging and microsatellite studies. Conserv Genetics 5:25-37.

Wu X-B, Wang Y-Q, Zhou K-Y, Zhu W-Q, Nie J-S, Wang C-L and Xie W-S (2002) Genetic variation in captive population of chinese alligator, Alligator sinensis, revealed by random amplified polymorphic DNA (RAPD). Biol Conserv 106:435-441.

Young B, Lips KR, Reaser JK, Ibáñez R, Salas AW, Credeño JR, Coloma LA, Ron S, Marca Ela, Meyer JR, et al. (2001) Population declines and priorities for Amphibian conservation in Latin America. Conserv Biol 15:1213-1223.

Zeisset I and Beebee TJC (2003) Population genetics of a successful invader: The marsh frog Rana ridibunda in Britain. Mol Ecol 12:639-646.

Zhang D-X and Hewitt GG (2003) Nuclear DNA analyses in genetic studies of populations: Practice, problems and prospects. Mol Ecol 12:563-584.

\section{Internet Resources}

Frost (2007) Amphibian Species of the World: An Online Reference. Version 4 (30 October 2006). Electronic. American Museum of Na tural History, New York. Available in: http:// research.amnh.org/herpetology/amphibia/index.php.

Funk WC, Greene AE, Corn PS and Allendorf FW (2005) High dispersal in a frog species suggests that it is vulnerable to habitat fragmentation. Biol Let 1-4. Available in: http:// www.royalsoc.ac.uk.

Associate Editor: Fausto Foresti 